\title{
Strategi Komunikasi Pemasaran Bagi Pelaku Usaha Makanan yang Terkena Dampak COVID-19
}

\author{
Nursha Dwi Setyowati ${ }^{1}$, Ririn Puspita Tutiasri ${ }^{2}$ \\ Program Studi Ilmu Komunikasi, UPN “Veteran” Jawa Timur \\ Email : nursha.ilkom@gmail.com
}

\begin{abstract}
Abstrack. In the midst of widespread government policies to maintain large-scale social distancing which have an impact on business actors, especially in this study, product business actors experience paralysis which results in decreased income. This requires food business actors to prepare the right strategy at least to stabilize income and maintain or get new consumers. The purpose of this research is to see how the marketing communication strategy for food product businesses has an impact on the impact of COVID-19. Qualitative research methods with a phenomenological approach. Data collection was carried out by interviewing the WhatsApp Call application and making bold observations. The results of this study indicate that food businesses affected by COVID-19 are combining offline to online marketing. On average, online in the Grab and Gojek food delivery application. So as not to leave the shop offline, develop its business by implementing $4 C$ marketing which is able to provide positive results because it prioritizes consumer needs.
\end{abstract}

Keywords: impact of COVID-19, 4C marketing communications, marketing communication strategy 4.0

\begin{abstract}
Abstrack. Di tengah merebaknya kebijakan pemerintah untuk menjaga jarak pembatasan sosial berskala besar berimbas bagi pelaku usaha khususnya dalam penelitian ini ialah pelaku usaha produk makanan mengalami kelumpuhan hingga mengalami penurunan pendapatan. Adanya hal tersebut perlunya pelaku usaha makanan menyiapkan strategi yang tepat setidaknya untuk menstabilkan pendapatan serta mempertahankan maupun mendapat konsumen baru. Tujuan dari penelitian ini untuk mengetahui bagaimana strategi komunikasi pemasaran bagi pelaku usaha produk makanan yang terkena dampak COVID-19. Metode penelitian ini kualitatif dengan pendekatan fenomenologi. Pengumpulan data dilakukan dengan wawancara melalui aplikasi WhatsApp call dan observasi secara daring. Hasil dari penelitian ini menunjukkan bahwa para pelaku usaha makanan yang terkena dampak COVID-19 mengombinasikan pemasaran offline ke online. Rata-rata secara online bekerjasama dengan aplikasi pesan antar makanan Grab dan Gojek. Sehingga tidak meninggalkan warung offline melainkan mengembangkan usahanya dengan menerapkan pemasaran $4 \mathrm{C}$ yang mampu memberikan korelasi yang positif karena mengutamakan kebutuhan konsumen.
\end{abstract}

Keywords: dampak COVID-19, komunikasi pemasaran 4C, strategi komunikasi pemasaran 4.0

\section{PENDAHULUAN}

Selama pandemi COVID-19 pemerintah telah merumuskan kebijakan untuk jarak fisik atau biasa kita kenal dengan PSBB. Pemerintah secara resmi mengumumkan bahwa masyarakat bekerja dari rumah (WFH), ditutupnya badan layanan umum, mengurangi jam operasional perdangangan dan memaksa masyarakat untuk memakai masker serta menjaga jarak sosial. Adanya kebijakan ini menimbulkan kontroversi karena beberapa layanan umum terpaksa ditutup karena alasan menjaga dan meminimalisir penyebaran virus.

Hingga akhirnya menyebabkan keadaan pelaku usaha khususnya dalam penelitian ini adalah pelaku usaha produk makanan mengalami penurunan pendapatan, terutama di kota-kota yang menerapkan PSBB mengalami lumpuh dan bahkan hampir bangkrut.Adanya hal tersebut pelaku usaha makanan memutar otak agar roda perekomonian tetap berputar. Maka permasalahan utama dalam hal ini pelaku usaha dituntut untuk lebih menyesuaikan diri terhadap situasi dan kondisi yang sedang 
terjadi dengan menyiapkan langkah-langkah dalam sebuah strategi yang tepat serta proses perencanaan yang matang sangat dibutuhkan olehnya.

Komunikasi pemasaran merupakan sebuah aktivitas yang bertujuan untuk menyampaikan informasi kepada konsumen,menumbuhkan perasaan suka terhadap merek atau produk, mendapat urutan pertama di hati konsumen dan menciptakan rasa yakin pada konsumen terhadap merek maupun produk (Machfoedz, 2010). Sedangkan strategi komunikasi sendiri merupakan suatu kegiatan komunikasi yang dilakukan oleh perusahaan guna untuk mencapai tujuan komunikasi yang dirancang sebagai tujuan perubahan. Selain itu strategi komunikasi khususnya dalam bidang pemasaran juga mengenai bagaimana mengkomunikasikan pengetahuan yang dibutuhkan konsumen sehingga mereka menyadari bahwa mereka membutuhkan produk tersebut (Suswanto \& Setiawati, 2020).

Definisi ini menunjukkan bahwa dalam pemasaran mencakup seluruh sistem kegiatan penjualan yang terencana meliputi penetapan harga, promosi, dan kegiatan pelayanan serta kualitas produk yang mampu memenuhi kebutuhan konsumen (Firmansyah, M. A., \& SE, 2020). Hal tersebut sejalan dengan pernyataan bahwaada banyak faktor yang mendukung para konsumen dalam melakukan pembelian, baik itu karena kebutuhan maupun keinginan. Sebelum melakukan pembelian, adakalanya konsumen tertarik dengan barang yang mereka beli karena barang tersebut menarik hati konsumen.Pada dasarnya, daya tarik orang terhadap subjek berbeda-beda. Ada yang tertarik dan langsung membelinya, ada yang melihat-lihatterlebih dahulu, begitupun muncul rasa keraguan dan bingung (Atmaja, Jaka et all., 2020).

Komunikasi pemasaran yang terencana mencakup teknik serta penggunaan media pemasaran yang tepat maka tujuan yang diinginkan oleh pemasar mudah tercapai. Menurut Anderson seperti hal yang dilakukan untuk mengombinasikan usaha dalam pemasaran online, yang diyakini berperan besar dalam mempengaruhi keunggulan prospek untuk berinteraksi dan mengambil keputusan bertransaksi (Supriyono, 2020). Hal tersebut sejalan dengan perkembangan web 4.0 yang mana menjadi "gong" perkembangan teknologi komunikasi dalam menunjang kehidupan, termasuk dalam kegiatan pemasaran. Jika sebelumnya kegiatan pemasaran berlangsung hanya secara konvensional saja, berbeda dengan pemasaran web 4.0 bisa menjalankan kegiatan pemasaran dari dua sisi seperti perpaduan antara pemasaran offline ke online. Keduanya justru akan mengisi peran masing-masing untuk melengkapi strategi pemasaran ini. Untuk itu agar kegiatan pemasaran web 4.0 lebih maksimal pelaku usaha dituntut untuk berkembang menghasilkan konten produk makanan yang relevan, menarik, upto-date untuk konsumen.

Pada era industri web 4.0 rata-rata pelaku usaha makanan memanfaatkan kecanggihan teknologi komunikasi.Hal ini dikarenakan untuk menarik konsumen sampai pada tindakan menganjurkan itu muncul, maka tetap dibutuhkan sentuhan dari produsen untuk menghasilkan pelayanan yang maksimal. Karena itu, konsep pemasaran 4.0 sendiri bertujuan untuk mengembangkan pemasaran yang mungkin sudah terbentuk sebelumnya (Tresyanto \& Ayu, 2019).

Menurut Kotler (dalam Fadly \& Sutama, 2020), pemasaran online adalah sistem kinerja perusahaan yang berfokus pada penjualan barang, jasa, atau kegiatan promosi yang berbasis internet. Produk yang dijual pada pasaran ini didapatkan secara online, sehingga konsumen yang hanya ingin melihat atau membeli bisa melihat tampilan produk tersebut tanpa harus langsung ke tokonya.Perkembangan berkelanjutan dari pemasaran berbasis internet atau online ini tidak hanya memberikan informasi dan pengetahuan tetapi, internet juga memberikan kemudahan bagi para pelaku usaha untuk menyampaikan maksudnya kepada konsumen.Jika dulu konsumen bertindak seperti pemirsa pasif (hanya menerima pesan yang dipaksakan oleh media), kini konsumen bergerak ke arah pemirsa aktif. Dalam model konsumsi konsumen aktif ini, konsumen tidak lagi pasif menerima pesan, 
tetapi secara aktif mencari merek / produk yang sesuai yang diinginkan dan dibutuhkan informasinya secara online.

Dalam penerapan tersebut guna mencapai tujuan daripada konsep pemasaran web 4.0 dapat terwujud, menurut Robert Lauterborn (dalam Kotler, 2002) pemasar perlu beradaptasi dengan mengaplikasikan strategi khusus dalam memasarkan produknya yakni dengan mempertimbangkan unsur elemen pemasaran 4C yang mana lebih mengutamakan kebutuhan konsumen agar kegiatan pemasaran lebih efektif meliputi :

1. Costumer (konsumen);

Adanya konsumen disini, agar pelaku usaha merancang alur yang mudah dipahami oleh konsumen, khususnya apabila berjualan menggunakan media online atau online shopping. Diantaranya konsumen merasa dimudahkan dalam alur pemesanan pembeliaan secara praktis dan tidak ribet.

2. Cost (biaya);

Adanya biaya disini, membuat para pelaku usaha mempertimbangkan penetapan harga. Pertimbangan tersebut meliputi kualitas produk yang sesuai dengan kebutuhan konsumen sehingga produk makanan yang dijual tersebut yang akhirnya membuat para konsumen bersedia membeli dengan harga sedemikian rupa. Adapun rata-rata para pelaku usaha juga menyediakan promo dan sistem berpaket.

3. Convinience (kenyamanan);

Kenyamanan juga merupakan salah satu yang konsumen inginkan ketika mereka sedang berbelanja produk.Oleh karena itu, pelaku usaha makanan mempertimbangkan kelayakan produk seperti cita rasa, kemasan produk, variasi produk dan lain-lain. Untuk itu perlunya mengetahui keinginan dan apa yang sedang dibutuhan serta diinginkan oleh konsumen.

4. Comunication (Komunikasi).

Komunikasi sangat penting digunakan untuk membangun interaksi dengan konsumen.Selain itu, karena jaman sekarang sudah semakin maju untuk berinteraksi dengan menggunakan saluran komunikasi. Dengan memberikan informasi yang jelas maka pesan yang diterima juga mudah dipahami.

Dengan mengombinasikan kegiatan pemasaran secara online ini juga memudahkan konsumen dari berbagai daerah secara mudah menemukan kebutuhannya melalui zona waktu yang berbeda tanpa bertemu satu sama lain, dan informasi tersedia di ribuan tempat. Selain itu, sistem pengiriman juga dapat bekerja sama dengan layanan online jasa pesan antar yang sangat membantu kegiatan pemasaran online (Fadly \& Sutama, 2020). Hal yang relevan dengan pernyataan tersebut yaitu menurut (Abidin Achmad et al., 2020) menyatakan pemasaran online menjadikan populer bagi kosumen di saat ini karena :

1. Kenyamanan serta keamanan konsumen dapat memesan produk selama 24 jam. Dimudahkan dengan tidak perlu mengemudi, mencari tempat, atau berjalan di gang yang panjang untuk mendapatkan barang. Mereka tidak harus pergi ke tempat, hanya untuk mengetahui bahwa produk yang mereka cari telah habis;

2. Mendapatkan informasi tentang penjual, produk, dan testimonial tanpa meninggalkan kantor atau rumah. Sehingga lebih selektif dalam hal harga, kualitas, performa dan ketersediaan.

Abidin Achmad juga mengungkapkan sedangkan bagi pemasar, adapun beberapa manfaat pemasaran online yaitu :

(1) Cepat beradaptasi dengan kondisi .pasar, penjual dapat dengan cepat menambahkan produk ke penawaran serta mengubah harga. 
ISSN. 2442-6962

Vol. 10. No. 1 (2021)

(2) Menurunkan biaya, mencegah biaya manajemen toko, persewaan, asuransi dan infrastruktur. Serta pembuatan katalog digital dengan biaya lebih rendah.

(3) Meningkatkan hubungan karena berjualan online dapat berkomunikasi secara dua arah, sehingga penjual bisa berinteraksi dengan konsumen.

(4) Ukuran minat pasar karena penjual tahu berapa banyak orang yang mengunjungi situs web mereka. Informasi ini dapat membantu penjual meningkatkan penawaran dan iklan mereka.

Melihat besarnya peluang serta beberapa kemudahan dan keuntungan yang didapatkan tersebut, disampaikan oleh Dirjen Penyelenggaraan Pos dan Informatika (PPI) Kominfo Ahmad M Ramli mengatakan selama pandemi COVID-19 jumlah transaksi online terus meningkat hingga menyentuh 400 persen. Melihat adanya prospek tersebut sejumlah pelaku usaha yang sebelumnya sudah ada berinisiatif mencoba peruntungan nasib mengombinasikan pemasaran online dalam kegiatan pemasarannya (Suryana, 2020)

Menjamurnya kegiatan pemasaran online sendiri tak luput adanya kepopuleran media, beberapa platfrom media tersedia, adapun media yang berbasis internet ini dikenal dengan media online. Media online sangat dibutuhkan sebagai media promosi dan alat pemasaran oleh para pelaku usaha makanan. Keberhasilan pemasaran online dengan penggunaan media online ini dipengaruhi oleh keakuratan penggunaannya. Karena setiap media online memiliki fungsi yang berbeda.Hal ini harus dipahami agar penggunaan media online menjadi efektif.Ada media online yang sangat cocok untuk menarik pengunjung, mempertahankan kunjungan, atau melibatkan pengunjung, dan lain sebagainya.

Di Indonesia sendiri terdapat media online yang sering kita jumpai layanan transportasi online jasa pesan antar seperti aplikasi Grab dan Gojek. Dalam aplikasi tersebut terdapat beraneka ragam layanan pesan antar salah satunya pesan antar makanan dari offline ke online.yang biasa dikenal dengan sebutan GoFood dan GrabFood. Jasa pesan-antar makanan tersebut memiliki banyak warung yang melayani dan menghubungkan warung dengan konsumen.Layanan online ini merupakan layanan bagi konsumen untuk memesan produk yang disediakan oleh produsen melalui saluran komunikasi seperti smartphone dan internet. Penyedia layanan pesan-antar menampilkan menu warung berserta harga di aplikasinya untuk menarik lebih banyak konsumen maupun mempertahankan konsumen, dan konsumen dapat memesan makanan secara online dan mengirimkannya ke lokasi yang telah ditentukan dalam waktu singkat (Nadif, 2019).

Di dukung dengan adanya pergeseran kebiasaan pola pembelian konsumen selama pandemi COVID-19 yang diungkapkan oleh aplikasi jasa pesan antar Grab dan Gojek perubahan itu diantaranya berbelanja online kemudian membeli makanan melalui GrabFood atau GoFood. Perusahaan Grab mencatat bahwa pemesanan makanan melalui aplikasi tersebut telah meningkat sebesar $10 \%$ sejak penerapan transisi Pembatasan Sosial Skala Besar (PSBB). Lain hal dengan yang dikatakan Andre selaku co-CEO Gojek selama masa pandemi corona ini layanan pesan antar makanan meningkat 7080\% (Burhan, 2020).

Berikut ini diantaranya keberhasilan sebuah strategi komunikasi pemasaran dari beberapa pelaku usaha makanan yang berinovasi agar usahanya tetap bertahan di tengah pandemi COVID-19 salah satunya dengan bekerja sama dengan mitra jasa layanan online pesan antar makanan. Seperti yang dilakukan oleh Dodi Sandra yang baru tiga bulan membuka toko online Pempek Pistel Kiarin di GoFood karena khawatir adanya pandemi ini usahanya akan mengalami kelumpuhan, Ia memutuskan bekerja sama dengan mitra layanan pesan antar Gojek. Di awal pandemi mitra pengemudi mengalami hantaman karena ada larangan mengangkut penumpang. Hal tersebut berbanding terbalik justru 
pemesanan makanan yang mengalami peningkatan Ia memperkirakan sekitar $70 \%$ pesanan masuk lewat layanan pesan antar online selama pandemi. Agar tetap menjaga pendapatan, Dodi secara gencar bergabung program promosi dan komunitas partner GoFood guna mengetahui informasi seputar kuliner yang sedang marak dikalangan konsumen(Burhan, 2020).

Hal tersebut juga dialami oleh pemilik usaha makanan yang bernama David selaku Owner Ayam Geprek yang berlokasi di Bali.Sejak merebaknya wabah COVID-19 justru omzet usaha semakin meningkat. Karena sejak 2017 telah bergabung menjadi partner GrabFood, dan yakin penjualan secara online ini dapat membantunya mempertahankan bisnis, sehingga tidak perlu memberhentikan karyawan. Selain itu, Ia terus berinovasi untuk bertahan hidup, seperti fokus di bisnis GrabKitchen. David juga menciptakan beberapa menu baru seperti paket harga murah yang mudah terjangkau oleh para konsumen (Burhan, 2020).

Adapun penelitian ini bertujuan untuk mengetahui bagaimana strategi komunikasi pemasaran yang dijalankan oleh pelaku usaha khususnya produk makanan yang terkena dampak COVID-19. Penelitian ini menjadi begitu penting karena penulis ber asumsi hal inidianggap mampusetidaknya untuk menstabilkan pendapatan serta mempertahankan maupun mendapat konsumen baru bagi pelaku usaha makanan apalagi di tengah pandemi saat ini.

Terkait hal tersebut terdapat beberapa penelitian terdahulu dari Priyo Suswanto dan Sri Dewi Setiawati dengan judul "Strategi Komunikasi Pemasaran Shopee Dalam Membangun Positioning di Tengah Pandemi Covid-19 di Indonesia" yakni menerapkan metode strategi kreatif isi pesan rasional, emosional dan moral melalui pemanfaatkan media serta celah konsumen dengan tepat.

Penelitian kedua berasal dari Lutfin dan Cita Fairuzah yang bernama "Strategi Komunikasi Pemasaran Toko Online Grey Cosmetics Pada Akun Shopee” Hasil penelitian menunjukkan bahwa strategi komunikasi pemasaran toko online "Grey Cosmetics" meliputi penerapan strategi komunikasi pemasaran melalui promosi , Mengaktifkan fungsi pengiriman gratis, strategi aktif mengikuti acara khusus dari shopee, strategi komunikasi pemasaran melalui tanggung jawab sebagai penjual produk dengan berupa pemberian gift (hadiah).

Penelitian ketiga yakni dari Indri Julianti dan Santi Delliana Dengan judul "Rebel Together Sebagai Strategi Komunikasi Pemasaran Digital Madformakeupdi Tengah Pandemi COVID-19” hasil penelitian ini menunjukkan, salah satu strategi yang digunakan Madformakeup adalah perencanaan strategi komunikasi pemasaran digital yang baik dan efektif, dengan menerapkan customer engagement melalui program Rebel Together menerapkan konsep STP dan IMC sehingga menghasilkan strategi komunikasi pemasaran digital yang dapat diterima oleh customer Madformakeup.

Sedangkan penelitian ini akan membahas tentang bagaimana strategi komunikasi pemasaran bagi pelaku usaha produk makanan yang terkena dampak COVID-19. Dalam strategi pemasaran tersebut, pelaku usaha makanan mengombinasikan antara penjualan secara offline ke online dengan bekerjasama melalui aplikasi layanan pesan antar makanan serta menerapkan elemen pemasaran 4C. Melalui fenomena yang telah disebutkan diatas, diharapkan para pelaku usaha lebih dapat mengembangkan usahanya.

\section{METODE PENELITIAN}

Jenis penelitian yang penulis gunakan yaitu penelitian kualitatif dengan pendekatan fenomenologi. Pengumpulan data dilakukan dengan wawancara secara daring melalui telefon di aplikasi WhatsApp Call dan observasi. Dalam penelitian ini observasi dilakukan secara daring melalui 
pengamatan aplikasi GrabFood dan GoFood dengan objek penelitian yang tepat untuk memperoleh keterangan atau data yang relevan dengan objek penelitian.

Dalam hal ini penelitian kualitatif difokuskan pada bagaimana pelaku usaha makanan menjalankan sebuah strategi komunikasi pemasaran dari offline ke online.Sedangkan pendekatan fenomenologi bertujuan untuk mendeskripsikan makna pengalaman hidup yang dialami.Untuk itulah penulis ingin mempelajari tentang pengalaman pelaku usaha produk makanan yang terkena dampak COVID-19 dalam studi fenomenologi ini.

Subjek penelitian ini ditentukan secara purposive sampling (berdasarkan kriteria tertentu).Standar subjek penelitian ini ditentukan berdasarkan teori dan disesuaikan dengan fokus penelitian. Penelitian ini menggunakan model analisis data interaktif menurut Miles dan Huberman dalam (Sugiyono, 2008). Kegiatan analisis data, meliputi : reduksi data, kategorisasi data, penyajian data, dan menarik kesimpulan.

\section{HASIL DAN PEMBAHASAN}

\section{Pengalaman Terkena Dampak COVID-19}

Dalam keadaan saat ini, COVID-19 menjadi pandemi pertama yang disebabkan oleh virus corona. Dampak COVID-19 juga dirasakan oleh berbagai kalangan salah satunya yaitu kelompok pelaku usaha makanan. Tentu pengalaman terkena dampak pandemi menjadi mimpi buruk olehnya. Maka dari itu setiap orang pasti memiliki cerita yang berbeda-beda juga solusi yang berbeda akan adanya imbas tersebut.

Berdasarkan hasil penelitian, rata-rata pelaku usaha makanan yang terkena dampak COVID19 mengalami kelumpuhan hingga penurunan pendapatan ketika masa PSBB ini. Seperti pengalaman yang dialami oleh pelaku usaha makanan jenis siap saji, bernama Surya selaku Owner Kedai Bu Jamilah. Menurut Surya "yang jelas sangat berdampak bagi pedangang. Terutama saat jam malam diperbatasi itu sangat mengurangi pendapatan, kurang efektif sebenarnya jam malam itu”.

Selama masa pandemi Surya mengalami pengalaman tersendiri dari adanya COVID-19 yakni ibunya yang bekerja di salah satu kedai kuliner sebelumnya menjadi dirumahkan sejak adanya pandemi ini. "jadi gini sebelumya ibu saya sudah berjualan di puja sera di daerah Kertosono, dan disitu tepatnya milik orang terus sistemnya bagi hasil, disitu itu sudah lama sekitar lima tahun lebih kemudian puja sera sama pemiliknya dijual ya mungkin karena faktor pandemi sekarang. Kemudian ibu saya sudah tidak jualan disitu lalu bingung mau jualan kemana. Lah terus mau nyari toko atau ruko buat jual di sekitar Kertosono dengan tempat yang seluas sebelumnya itu harga nya sangat mahal tidak terjangkau" karena kegaduhan tersebut Surya memutar otak agar usahanya tetap berjalanan yang akhirnya tertarik untuk mencoba peruntungan nasib bekerjasama dengan Grab sejak tanggal 6 September 2020, sedangkan Gojek tanggal 12 Oktober 2020.

Informan lain yang juga pernah mengalami kelumpuhan hingga pendapatan yang menurun yaitu pelaku usaha makanan olahan ayam yang sudah berdiri sejak 2018, Owner Hero Chicken yang bernama Diki menyatakan "dulu waktu awal penerapan PSBB iya sempet ndak jalan wong ya apa itu lumpuh gitu lo bisa jadi karena warga sekitar waktu itu mungkin takut gitu ya beli makan diluar rumah. Atau mungkin juga kan dulu juga marake korban PHK'an itu to mbak sehingga faktor ekonomi keluarga jadi berkurang gitu terus mengurangi beli makan diluar karena irit, yang akhirnya ya sempet sepi jualanya secara tidak langsung pendapatan juga tidak seperti biasanya sebelum PSBB". Diki selaku Owner Hero Chicken memutuskan menggunakan layanan pesan antar makanan sekitar bulan Agustus 2020. 
Adapun pernyataan lain dari pelaku usaha jenis makanan jenis sambelan yang mendaftarkan dua warungya sekaligus di aplikasi pesan antar makanan. Fitria selaku Owner dari Dapur Pinggir Rel dan FF Food, yang juga merasakan dampak langsung dari pandemi COVID-19 hingga pendapatan omset yang berbeda dengan sebelumnya. Fitria menyatakan "sangat mengalami di masa pandemi segitu berkurang karena kan orang juga ekonomi melemah seтиa kan di ospek apapun, jadi ya melemah sih". Hingga akhirnya sekitar awal tahun 2020 Ia mengombinasikan pemasaran secara offline to online dengan bekerjasama melalui aplikasi pesan antar makanan Grab sekaligus Gojek.

Selanjutnya pelaku usaha makanan jenis bakso yang sudah berdiri sejak puluhan tahun pun juga mengeluh karena usahanya juga terkena dampak langsung dari pandemi COVID-19. Pelaku usaha makanan tersebut bernama Iis selaku Owner Bakso Moro Seneng yang mana warung tersebut merupakan usaha keluarga. Iis menyatakan "iya yang offline itu sudah lama ya puluhan tahun, terus Alhamdulillah lancar tapi ya karena pandemi ini dan kebijakan pemerintah yang harus aaa pembatasan aktivitas diluar rumah jadi ya sangat berdampak sih bagi pedagang, saya juga merasakan seperti itu orangtua saya. Terus ini akhirnya dari orangtua saya mengeluh seperti itu". Adanya keluhan dari orangtuanya tersebut Iis selaku generasi muda dikeluarganya berinisiatif untuk mendaftarkan warungnya di jasa layanan pesan antar tersebut. Akhirnya, Bakso Moro Seneng memutuskan bekerjasama dengan layanan pesan antar makanan sejak tiga bulan yang lalu yaitu sekitar bulan November 2020.

Selain itu, Putri selaku Owner Kasushie Kertosono sudah berdiri 4 tahun yang lalu juga termasuk terkena imbas dari adanya pandemi saat ini. Dalam usahanya Ia sempat merumahkan dua pekerjanya karena warungnya sejak pandemi saat ini mengalami penurunan omset "iya karena itu juga mbak saya join ke aplikasi grab dan gojek. Karna sejak corona ini daya beli masyarakat tuh berkurang mbak, dagangan tak serame dulu, sebelumnya juga banyak yang pada makan ditempat akhir2 ini berkurang mbak. Ya begitulah. saya Menyiasati dengan join aplikasi mbak”. Untuk itu Ia berinisiatif untuk bangkit agar usahanya tetap berjalan dengan mendaftarkan warungnya ke aplikasi pesan antar grab dan gojek sejak 22 Februari 2020.

Informan selanjutnya yaitu Owner Kedai Selera Nusantara bernama Agus. Warung yang bertepatan di depan kampus ini berdiri sudah 7 tahun, ikut terkena imbas adanya pandemi saat ini "iya jelas sempet lumpuh karena merasa sepi warung nya gak kayak biasanya yang banyak buat tempat nongkrong mahasiswa, kan saya jualannya di depan kampus mbak jadi ya juga berdampak gitu" karena adanya penurunan tersebut salah satu karyawannya menyarankan mendaftarkan warung tersebut ke aplikasi pesan antar gojek. Hingga akhirnya Kedai Selera Nusantara mulai tersedia dalam aplikasi sejak Juni 2020.

Terdapat 2 informan pelaku usaha makanan yang baru saja berdiri menyatakan bahwa mereka mendaftarkan warungnya ke aplikasi layanan pesan antar tersebut supaya lebih dikenal oleh konsumen secara luas karena mengingat warung baru berdiri dan belum banyak konsumen yang mengetahui. Seperti yang dikatakan oleh Nurmalita selaku Owner Potner Corner dan Novita selaku Owner Camme Food. Warung tersebut baru berdiri sejak masa pandemi saat ini dan belum genap satu tahun berdiri, lalu berinisiatif mengombinasikan dari offline ke online guna memudahkan konsumen untuk menemukan apa yang dibutuhkan melalui aplikasi pesan antar makanan tersebut.

Hal tersebut terjadi karena rata-rata konsumen telah mengalami pergeseran kebiasaan baru pola pembelian konsumen yaitu berbelanja secara online ditambah dengan mematuhi peraturan baru dari pemerintah untuk mengurangi aktivitas yang dilakukan diluar rumah sehingga berkurangnya keinginan untuk membeli makanan diluar adapun karena faktor ekonomi turut serta dalam hal ini 
seperti yang dikatakan oleh Menteri Keungan Sri Mulyani. Adanya pernyataan tersebut para pelaku usaha berinisiatif mengombinasikan pemasaran offline ke online. Juga terbesit keinginan untuk memperluas jangkauan segment pasar tentunya untuk memenuhi kebutuhan peningkatan pelayanan guna menarik hati para konsumen.

\section{Strategi komunikasi pemasaran 4.0}

Menurut Burhan Bungin, strategi komunikasi merupakan suatu kegiatan komunikasi yang dilakukan oleh perusahaan guna untuk mencapai tujuan komunikasi yang dirancang sebagai tujuan perubahan. Selain itu strategi komunikasi khususnya dalam bidang pemasaran juga mengenai bagaimana mengkomunikasikan pengetahuan yang dibutuhkan konsumen sehingga mereka menyadari bahwa mereka membutuhkan produk tersebut (Suswanto \& Setiawati, 2020).

Agar dapat mempertahankan dan memenangkan hati konsumen diperlukannya strategi pemasaran 4.0 menurut Philip Kotler (dalam Tresyanto \& Ayu, 2019) bahwa teori pemasaran 4.0 atau pemasaran digital merupakan pendekatan pemasaran baru, pelaku usaha makanan dituntut untuk beradaptasi memanfaatkan sifat teknologi komunikasi yang canggih dan praktis. Pasalnya, untuk menarik konsumen dan merekomendasikan tindakan, produsen tetap perlu bekerja keras untuk memberikan layanan yang maksimal. Oleh karena itu, pemasaran web 4.0 sendiri bertujuan untuk mengembangkan pemasaran yang mungkin sudah terbentuk sebelumnya. Adanya aplikasi pesan antar makanan tersebut menjadi daya tarik tersendiri di kalangan para pelaku usaha makanan.

Beberapa informan pelaku usaha makanan memanfaatkan peluang dengan tetap melakukan aktivitas usaha seperti biasa namun tetap mematuhi protokol kesehatan. Sehubung dengan itu, berikut beberapa hasil wawancara mengenai bagaimana penerapan strategi kombinasi antara pemasaran offline ke online yang dijalankan oleh pelaku usaha makanan yang terkena dampak COVID-19. Beberapa informan menyatakan jika kombinasi strategi pemasaran ini benar dapat menjadi solusi bagi para pedagang setidaknya untuk menstabilkan pendapatan juga mempertahankan maupun mendapat konsumen yang baru.

Seperti yang dikatakan oleh Owner Bakso Moro Seneng "saya sebagai generasi muda di keluarga lalu saya yang mengusulkan, gimana kalo ditambah promosinya di sosial media. Kalo ini aku bantu juga di instagram mbak, aku kebetulan membuat instagram khusus jualan ini, terus aku infokan disitu ada juga kek stiker gitulo mbak aku tempel di depan warung offline itu jadi kalo ada yang beli bisa liat kalo tersedia di grabfood juga gitu. Apalagi sekarang itu canggih mbak ya alat teknologi pastinya semua mudah tahu informasi online jadi saya pengen coba di grabfood pesan antar tadi. Ya kalo menurut saya bisa menjangkau promosi nya sih mbak, soalnya kan orang pengen praktis gitu apalagi masa pandemi"

Pernyataan yang linier juga disampaikan oleh Diki selaku Owner Hero Chicken yang melakukan pembeharuan pelayanan sesuai dengan perkembangan jaman, "hmm ya karena dulu itu kan kepikiran karena musim PSBB semuane kan serba dibatasi gitukan mbak dan juga sekarang itu sudah masuk jaman digital lalu ya kepikiran aja join ke aplikasi yang bisa luas gitu promosine. Ya bisa dibilang up to date mengikuti perkembangan jaman. Adapun promosi lain juga melalui media sosial terus di wadah kemasannya saya cantumin label kontak hero chicken, kalo mbak minat saget mbake"

Hal tersebut juga diterapkan oleh para pelaku usaha yang baru saja memulai usahanya. Seperti yang dialami oleh Owner Camme Food "ya karena sekarang kan serba online, apabila masa pandemi saat ini tuh orang makin males gitulo buat keluar rumah, beli langsung, mereka lebih 
ngandelin handphone otomatis semuanya serba online, pesenya online, pesen makanan pun online gitu jadi aku pikir ya kenapa gak gitu toh daftar grab juga gak mbayar dan gampang"

Adapun hal lain yang disampaikan oleh pelaku usaha makanan Owner FF Food dan Dapur Pinggir Rel "lewat media sosial sangat penting, kayak WhatsApp, Instagram, dan Facebook. Paling utama Facebook sih. Karena lebih cepat dikenal banyak orang, nah disana itu ada grup namanya kuliner Kertosono jadi mencakup penjual makanan-makanan tuh yang di Kertosono. Nah ada yang ngebatin resto sini ternyata ada grab/gojeknya nih jadi lebih mudah gitu kalo saya gak bisa nganter"

Informan Owner Potner Corner yang mana juga menfaatkan adanya aplikasi pesan antar makanan tersebut "yang pertama kan karena kita gak bisa nganterin terus menerus ke pelanggan, makannya kita perlu bantuan grab/gojek ini. Terus di aplikasi itu secara tidak langsung kita dapat promosi dan jangkauannya jauh lebih luas. Kalo dulu hanya sekedar kontak WhatsApp saja dan dekat-dekat saja tapi setelah join ini jangkauan jadi lebih luas yang beli juga dari orang yang tidak kita kenal juga."

Owner Kedai Bu Jamilah menyatakan melakukan kombinasi tersebut dengan memberi label khusus pada bungkus makanan tersebut sehingga memudahkan konsumen "kemudian saya inisiatif untuk jualan buka sendiri di rumah dan join ke Grab sama Gojek saja. Saya join pertama itu kita pemasarannya sudah jaman digital, jadi kita pemasaran lewat Facebook, Instagram, WhatsApp. Lalu kalau ada yang beli itu di bungkusnya ada stiker yang bertuliskan Kedai Bu Jamilah dan nomor kontaknya gitu”

Owner Kasushie Kertosono berusaha memberikan informasi kepada para pelanggannya dengan sebuah banner maupun di meja kasir pemberitahuan warungnya sekarang sudah tersedia dalam aplikasi pesan antar makanan "saya itu promosi di media sosial begitu, bikin caption yg menarik ngasih informasi kalo kasushie tersedia di grab dan gojek gitu mbak terus juga saya kasih banner di depan warungnya, di meja kasir juga saya kasih keterangan informasi, gitu sih mbak"

Selanjutnya Owner Kedai Selera Nusantara dalam mengombinasikan pemasaran offline ke online yaitu dengan promosi melalui media sosial juga dengan banner di depan warungnya agar para konsumen mengetahui perkembangan dari warungnya tersebut "promosi lewat WA, instagram, dan Facebook, juga di depan warung saya kasih stand banner kalo ini tersedia di gojek gitu”

Berdasarkan hasil wawancara beberapa pertimbangan yang akhirnya membuat para pelaku usaha makanan mengombinasikan sistem pemasaran tentunya dapat meningkatkan efektivitas pemasaran produk makanan dan juga karena terdapat kemudahan yang didapat, selain itu mendukung program pemerintah untuk mengurangi kerumunan sehingga lebih aman, serta biaya promosi lebih terjangkau, dan tentunya memperluas segment pasar.

\section{Pemasaran Melalui Aplikasi Grab atau Gojek}

Aplikasi Grab atau Gojek merupakan aplikasi jasa pesan antar makanan yang lebih dikenal dengan sebutan GrabFood atau GoFood. Dalam aplikasi tersebut terdapat beberapa pilihan jenis menu makanan, dari yang berat hingga makanan ringan yang siap antar ke lokasi konsumen sehingga mempermudah proses distribusi terlebih di masa pandemi COVID-19 saat ini, yang mana jika ingin bertahan maka pelaku usaha makanan dituntut mampu memanfaatkan perkembangan digital salah satunya dengan cara beradaptasi mendaftarkan usaha warungnya ke aplikasi tersebut. Hal ini juga sejalan dengan penelitian (Purwana et al., 2017) bahwa pelaku usaha perlu memiliki keberanian untuk mencoba hal-hal baru seperti digital marketing untuk dapat lebih mengembangkan usahanya. 
ISSN. 2442-6962

Vol. 10. No. 1 (2021)

Berdasarkan hasil wawancara rata-rata para pelaku usaha makanan seperti Potner Corner, Kedai Bu Jamilah, Hero Chicken, Kasushie Kertosono, Dapur Pinggir Rel dan FF Food bekerja sama dengan GrabFood dan GoFood, karena Ia mampu belajar beradaptasi dengan perkembangan jaman dengan mengikuti langkah-langkah pendaftarkan warungnya tersebut dengan melihat panduan dari Website resmi maupun tutorial di Youtube.

Informan lain Bakso Moro Seneng dan Camme Food hanya menggunakan GrabFood saja, lalu Kedai Selera Nusantara hanya menggunakan GoFood saja dikarenakan masing-masing mengalami kendala ketika proses pendaftaran warungnya, adapun hal lain karena kurangnya jiwa untuk beradaptasi dengan perkembangan jaman yang mana akhirnya hanya bisa mendaftarkan usahanya ke satu aplikasi saja.

Dengan mendaftarkan warungnya ke aplikasi tersebut pelaku usaha makanan tersebut setidaknya memiliki pendapatan tambahan dan sangat berkorelasi positif terhadap perkembangan usaha makanan di tengah pandemi karna mencakup kepraktisan karena secara intensif dapat mengomunikasikan keberadaan produk makanan selain itu dapat meningkatkan kepercayaan konsumen, keamanan dan kenyamanan.

\section{Mengutamakan Kebutuhan Konsumen}

Sebagai kebutuhan pokok produk makanan ini memiliki segmentasi pasar yang beragam karena semua tingkatan umur membutuhkan makanan, baik dari segi komposisi, cita rasa, patokan harga, nilai gizi, bentuknya maupun pilihan varian makanannya. Dalam kondisi pandemi saat ini pelaku usaha makanan mesti memiliki kemampuan inovasi menyesuaikan dengan selera dan tuntutan konsumen menjadi sangat penting tentunya dengan menerapkan pemasaran 4C. Penelitian terdahulu yang relevan dengan pernyataan tersebut menyatakan bahwa adanya peningkatan pada kualitas produk serta kualitas layanan memiliki peran positif dan penting dalam membangun kepuasan konsumen. Oleh karena itu, pada saat pandemi COVID-19, pelaku usaha perlu fokus pada dimensi kualitas produk dan meningkatkan produknya untuk meningkatkan kepercayaan konsumen (Tripayana \& Pramono, 2020).

Adapun seluruh informan pelaku usaha makanan yang terkena dampak COVID-19 dalam penelitian ini semua mengutamakan kebutuhan konsumen dengan melakukan peningkatan dalam hal kualitas produk maupun pelayanan tentuanya dari sisi Costumer, Cost, Convinience dan Communication.

\section{Costumer}

Penting bagi pelaku usaha makanan untuk menjaga dan merawat hubungan yang baik kepada konsumen dengan mempertahakankan loyalitas konsumen. Loyalitas konsumen pada produk makanan yaitu dengan memberikan jaminan kualitas dari produk makanan tidak berubah termasuk juga dengan pemilihan tempat promosi yang tepat sesuai dengan kebutuhan konsumen. Dengan menggabungkan usaha melalui aplikasi jasa pesan antar makanan GoFood dan GrabFood, konsumen merasa dimudahkan dalam mencari kebutuhan produk makanan yang diinginkan kapan pun dan dimana pun terlebih di masa pandemi saat ini.

\section{Cost}

Mempertimbangkan patokan harga yang wajar dan tidak dilebihkan kepada konsumen. Hal tersebut biasa ditujukan dengan memberikan promo dari makanan maupun promo ongkos kirim, selain itu juga memberlakukan sistem berpaket yaitu diterapkan oleh Owner Kasushie Kertosono, Hero Chicken, Potner Corner, Dapur Pinggir Rel dan FF Food. Berbeda dengan Bakso Moro Seneng, 
ISSN. 2442-6962

Vol. 10. No. 1 (2021)

Camme Food, dan Kedai Jamilah mereka mempertimbangan harga satuan. Dan untuk Kedai Selera Nusantara menggunakan sistem berpaket saja sudah dianggap cukup terjangkau di kalangan konsumen.

\section{Convinience}

Kenyamanan karena tidak perlu keluar rumah dan juga tidak perlu antri dengan pembeli yang lain. Menyajikan makanan dengan keadaan selalu fresh di setiap harinya sehingga cita rasa nya tetap terjamin, Selain itu pilihan menu variasi produk makanan, juga untuk menarik perhatian konsumen.

\section{Communication}

Berusaha memberikan informasi kepada konsumen akan kehadiran warungnya tersedia dalam aplikasi pesan antar tersebut melalui media sosial, selain itu penampilkan produk disertai gambar yang menarik juga dengan bahasa yang mudah dimengerti dan informatif dengan memberikan tampilan pemisah kategori jenis makanan dengan minuman sehingga konsumen lebih mudah mengerti akan pesan yang ditampilkan dalam aplikasi tersebut.

\section{KESIMPULAN}

Seperti yang terlihat dalam hasil, salah satu kunci strategi komunikasi pemasaran bagi pelaku usaha makanan yang terkena dampak COVID-19 yaitu mengombinasikan pemasaran offline ke online diantaranya bekerja sama dengan jasa pesan antar makanan Grab dan Gojek. Karena dapat meningkatkan efektivitas pemasaran produk makanan dan kemudahan yang didapat, selain itu mendukung program pemerintah untuk mengurangi kerumunan sehingga lebih aman, serta biaya promosi lebih terjangkau, dan tentunya memperluas segment pasar.Sehingga tidak meninggalkan warung offline melainkan mengembangkan usahanya. Hal pendukung lainnya yang dilakukan oleh pelaku ushaa makanan ialah menerapkan pemasaran 4C yang mampu memberikan korelasi yang positif karena mengutamakan kebutuhan konsumen. Diantaranya costumer (konsumen) dengan mudah mendapatkan apa yang sedang dibutuhkan secara aman dan praktisjuga dari sisi convinience (kenyamanan) meliputi kualitas produk yang mampu disesuaikan dengan kebutuhan konsumen diantaranya selalu fresh mengutamakan cita rasa, untuk Cost (harga) memang rata-rata belum menerapkan sistem promo dan paket, namun tetap menampilkan penjelasan menu makanan yang informatif pada aplikasi agar pesan yang disampaikan mudah dipahami. Pelaku usaha makanan juga berusaha menjaga communication (komunikasi) agar tetap terjalin secara soft selling promosi melalui media sosial lainnya.

\section{DAFTAR PUSTAKA}

Abidin Achmad, Z., Zendo Azhari, T., Naufal Esfandiar, W., Nuryaningrum, N., Farah Dhilah Syifana, A., \& Cahyaningrum, I. (2020). Pemanfaatan Media Sosial dalam Pemasaran Produk UMKM di Kelurahan Sidokumpul, Kabupaten Gresik. Jurnal Ilmu Komunikasi, 10(1), 17-31. https://doi.org/10.15642/jik.2020.10.1.17-31

Aminul. (2020). Perilaku Produksi Di Tengah Krisis Global Akibat Pandemi Covid-19 Dan Memanfaatkan Media Online Facebook Sebagai Alternatif Pasar. EMISI (Jurnal Ekonomi, Manajemen dan Akuntansi).

Atmaja, Jaka et all. (2020). Analisis Pengaruh Daya Tarik Dan Strategi Pemasaran Terhadap Kepuasan Berbelanja Di Rumah Oxcart. Jurnal Ilmu Komunikasi (J-IKA), 7(2), 148-154.

Burhan, F. A. (2020). Artikel ini telah tayang di Katadata.co.id dengan judul "Siasat Gojek dan Grab Saingi Tokopedia-Shopee yang Ikut Jual Makanan”.katadata.co.id. https://katadata.co.id/desysetyowati/digital/5f1a9ef55a9d9/siasat-gojek-dan-grab-saingi- 
ISSN. 2442-6962

Vol. 10. No. 1 (2021)

tokopedia-shopee-yang-ikut-jual-makanan

Fadly, H. D., \& Sutama. (2020). Membangun pemasaran online dan digital branding ditengah pandemi covid-19. Jurnal Ecoment Global : Kajian Bisnis dan Management, 5, 213-222.

Firmansyah, M. A., \& SE, M. (2020). Komunikasi Pemasaran. Qiara Media.

Kotler, P. (2002). Manajemen Pemasaran,Edisi Milenium. PT.Prehalindo.

Machfoedz, M. (2010). Komunikasi pemasaran modern. Yogyakarta: Cakra Ilmu, 139.

Nadif, A. S. (2019). Strategi Pemasaran Online Food Delivery Grab Food Pada Wirausaha (Study Kasus Kedai Mie Bajak Pangarangan Sumenep). Universitas Wiraraja.

Purwana, D., Rahmi, R., \& Aditya, S. (2017). Pemanfaatan Digita 1 Marketing Bagi Usaha Mikro, Kecil, Dan Menengah (UMKM) Di Kelurahan Malaka Sari, Duren Sawit. Jurnal Pemberdayaan Masyarakat Madani (JPMM), $\quad$ 1(1), 1-17. https://doi.org/10.21009/jpmm.001.1.01

Sugiyono. (2008). Metode penelitian pendidikan:(pendekatan kuantitatif, kualitatif dan $R \& D$ ). Alfabeta.

Supriyono, S. (2020). Media Sosial Sebagai Alat Promosi Yang Efektif Bagi Usaha Rintisan di Era Normal Baru. Prosiding Seminar STIAMI, 7(2), 53-61.

Suryana, W. (2020). Penjualan Daring Naik 400 Persen Selama Pandemi. republika.co.id. https://republika.co.id/berita/qapi4h459/penjualan-daring-naik-400-persen-selama-pandemi

Suswanto, P., \& Setiawati, S. D. (2020). Strategi Komunikasi Pemasaran Shopee Dalam Membangun Positioning Di Tengah Pandemi Covid-19 Di Indonesia. Linimasa: Jurnal Ilmu Komunikasi, 3(2), 16-29. http://52.221.78.156/index.php/linimasa/article/view/2754

Tresyanto, C. A., \& Ayu, S. A. (2019). Penerapan Strategi Marketing 4 . 0 Papa Wisata Museum Sepuluh November (Tugu Pahlawan Surabaya). 4, 341-356.

Tripayana, S., \& Pramono, J. (2020). Kualitas Produk, Pelayanan, dan Loyalitas Pelanggan Dimana Kepuasan Sebagai Variabel Intervening pada UKM Start Up Pariwisata Kombuchi Brewing Co, Bali. Jemap, 2(2), 182. https://doi.org/10.24167/jemap.v2i2.2266 